\title{
Mumbai 1998
}

\author{
By Ron Holloway
}

Spring 1999 Issue of KINEMA

\section{MUMBAI INTERNATIONAL FILM FESTIVAL FOR DOCUMENTARY, SHORT AND AN- IMATION FILMS 1998}

Founded in 1990 as a biannual event, and now only five festivals old, the 5th Mumbai (Bombay) International Film Festival for Documentary, Short and Animation Films (1-7 March 1998) already numbers among the most important of its kind. Indeed, MIFF pulled out all the stops this year to celebrate India's 50 Years of Independence in the country's largest city and undisputed finance-and-film capital, where the Films Division has been chronicling the country's history, culture and heritage with scores of documentaries over the past five decades.

Altogether, including retrospectives and the information section, over 300 films and videos were programmed by festival director Bankim. Two juries, for film and video entries, awarded 22 prizes and citations, along with purses amounting altogether to $\$ 45,000$ (1.8 million rupees). Golden and Silver Conches were awarded in four film categories: Long Documentary (over 40 minutes), Short Documentary, Short Fiction Film (under 60 minutes), and Animation Film. A separate jury selected the Best Video from among entries by Indian directors, an Indian Critics Jury awarded a Press Prize to the Best Long Documentary, and the Indian Documentary Producers Association decided spontaneously on opening night to grant an IDPA Trophy for Director's First Film.

Cineastes from across the Subcontinent crowded into the Nehru Centre and four other venues for festival screenings. Of particular interest were the retrospectives honoring Chilean documentarist Patricio Guzman, French video poet Robert Cahen, and Indian documentarists Mani Kaul, Promod Pati, and Anand Patwardhan. The Indian Film Archive in Poona assembled a retro, "50 Years of Indian Documentary," on the occasion of the 50th anniversary of independence, among these the only Indian film nominated for an Oscar: Fali Bilimoria's The House That Ananda Built (1968). In addition, special screenings of Oberhausen Prizewinners and documentaries produced at Studio D at the National Film Board of Canada were on the schedule. And the late Bert Haanstra (1916-1997) was honored with a homage.

John Edginton's Mumia Abu-Jamal: A Case for Reasonable Doubt (UK), a long documentary awarded both the Golden Conch and the Press Prize, was the most discussed film of the festival. In his well researched report on the murder of a Philadelphia policeman and the still undecided fate of the accused defendant sitting on death row, the director gradually shifts the viewer's attention away from the murder to focus on a possible miscarriage of justice due to a lack of convincing evidence. Golden Conches were also awarded to V. Packiriswamy's Bhiwandi Tragedy (India), a short documentary on the sad plight of migrant workers and the shocking news of fatal food poisoning on a construction site; Vangelis Kalambakas's Little Preludes (Greece), a short fiction film linking events in an apartment building with a lively Bach score played by a young girl on a piano; and Gerrit van Dijk's I Move, So I Am (Netherlands), a delightfully constructed animation film on converging movements in art history that won the filmmaker a Golden Bear at the Berlinale but a week before.

\section{References}

\section{AWARDS}

Long Documentary:

Golden Conch: John Edginton's Mumia Abu-Jamal: A Case for Reasonable Doubt (UK);

Silver Conch: Lutz Leonhardt's Zakir and His Friends (Switzerland);

International Jury Award (ex aequo): Michael Uys and Lexy Lovell's Riding the Rails (USA) and Sehjo Singh's Kol Tales (India); 
Certificate of Merit for Lifetime Achievement: Johan van der Keuken's Amsterdam Global Village (Netherlands);

Indian Critics Award: John Edginton's Mumia Abu-Jamal: A Case for Reasonable Doubt (UK).

\section{Short Documentary:}

Golden Conch: V. Packiriswamy's Bhiwandi Tragedy (India);

Silver Conch: Galina Leontieva's The Bell's Breath (Russia);

IDPA Trophy for Director's First Film: Sergio Block's Donkey without a Tail (Brazil);

\section{Short Fiction Film:}

Golden Conch: Vangelis Kalambakas's Little Preludes (Greece);

Silver Conch: Bill Morrison's The Film of Her (USA-Italy);

Certificates of Merit: Maria von Heland's Chain Smoker (Germany) and Fiona Cochrane's Gorilla Girls (Australia);

Special Mention by Indian Critics: Vangelis Kalambakas's Little Preludes (Greece).

\section{Animation Film:}

Golden Conch: Gerrit van Dijk's I Move, So I Am (Netherlands);

Silver Conch: Joel Simon's Ciderpunks (Ireland -UK);

Certificate of Merit: Anurag Jauhari's The Lift (India).

\section{Indian Video Awards}

Golden Conch, Short Documentary Video, Amar Kanwar's A Season Outside;

Silver Conch: Long Documentary Video: Stalin K.'s Lesser Humans;

Best Video Animation: Bhimsain's The Prince and the Musician,

Certificates of Merit: Saba Dewan's Snow (Long Documentary), K.P. Jayasankar and Anjali Monteiro's YCP 1997 (Short Documentary), and Sameera Jain's Portraits of Belonging-- Bhai Mian (Short Documentary).

\section{Author Information}

Ron HOLLOWAY (1933-2009) was an American critic, film historian, filmmaker and correspondent who adopted Europe as his home in the early fifties and spent much of his life in Berlin. He was an expert on the study of German cinema and against all odds produced, with his wife Dorothea, the journal German Film, keeping us up-to-date with the work of directors, producers and writers and the showing of German films around the world.

In 2007, Ron Holloway and his wife were awarded the Berlinale Camera Award. Ron also received the Bundesverdienstkreuz (German Cross of Merit), Polish Rings, Cannes Gold Medaille, the American Cinema Foundation Award, the Diploma for Support of Russian Cinema and an honorary award from the German Film Critics' Association.

Ron was also a valued contributor to Kinema for the past fifteen years. 